IR スペクトル（KBr 錠剂法，以下同じ）： $\nu_{(\mathrm{C}-\mathrm{O}-\mathrm{C})} 1286$; $\nu_{\left(\mathrm{NO}_{2}\right)} 1351,1515 ; \nu_{(\mathrm{C}-\mathrm{F})} 1118 \mathrm{~cm}^{-1}$ 。

また 3-フルオル-4-クロルニトロベンゼン $5.26 \mathrm{~g}, 4-$-ニトロフ エノールのカリウム塩 $5.26 \mathrm{~g}$ 打よび DMSO $12 \mathrm{ml}$ の混合物を 2 時間者沸遥流させたのち内容物を氷水中にあけ, 沈殿をこしわ

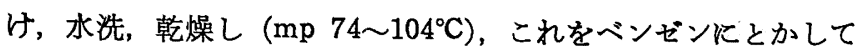
アルミナカラム中に展開させ，黄色のバンドをベンゼンで溶出 し, 溶出液を蒸発乾固して $\mathrm{mp} 96 \sim 113^{\circ} \mathrm{C}$ の結晶 $5.5 \mathrm{~g}$ (66\%) をえた。エタノールから再結晶して $\mathrm{mp} 115 \sim 116^{\circ} \mathrm{C}$, 先の別途 合成品と混融して融点の降下を示さず，同一物であることを確認 した。

$$
2 \cdot 52,2 \text { '-ジフルオル-4, 4'-ジニトロジフェニルエーテル }
$$

2-フルオル-4-ニトロフェノール $55 \mathrm{~g}$ をエタノール $55 \mathrm{ml}$ に とかし，水酸化カリウム（純度 $85 \%$ ） $20.7 \mathrm{~g}$ をメタノール 60 $\mathrm{m} l$ にとかした液を室温で少しずつ加えて中和し，生じた結晶を

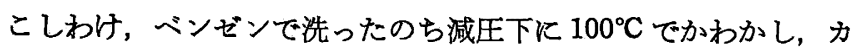
リウム塩 $61 \mathrm{~g}(89 \%)$ をえた。

このカリウム塩 $42 \mathrm{~g}$ 执よび 4-クロル-3-フルオルニトロベン ゼン $47 \mathrm{~g}$ を DMSO $100 \mathrm{ml}$ にあたためてとかし，さらに 5 時間 煮沸還流させたのち放冷し，反応液を氷中にそそぎ，生じた沈沮 をこしわけ,メタノールで洗って油状物を除き，かわかして粗製 物 $60 \mathrm{~g}$ をえた。これをベンゼン $300 \mathrm{ml}$ にとかし，少量の不純 物をのぞいたのちアルミナカラム上に展開させ, ベンゼンで黄色

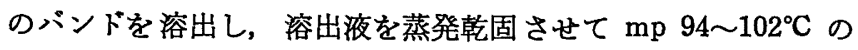
結晶 $54 \mathrm{~g}(76 \%)$ をえた。エタノールから 1 回再結晶して mp $103 \sim 104^{\circ} \mathrm{C}$ 。

分析値 F $12.5 \%, \mathrm{~N} \mathrm{9.31 \%}$
$\mathrm{C}_{12} \mathrm{H}_{6} \mathrm{~F}_{2} \mathrm{~N}_{2} \mathrm{O}_{5}$ としての計算值 F $12.8 \%, \mathrm{~N} 9.46 \%$

IR スペクトル： $\nu_{(\mathrm{C}-\mathrm{O}-\mathrm{C})} 1285 ; \nu_{\left(\mathrm{NO}_{2}\right)} 1345,1525 ; \nu_{(\mathrm{C}-\mathrm{F})}$ $1130 \mathrm{~cm}^{-1}$ 。

$2 \cdot 62,2$-ジフルオル-4, 4'-ジアミノジフェニルエーテル

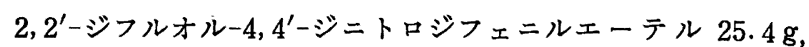
$80 \%$ ヒドラジンヒドラート水溶液 $42 \mathrm{ml}$, エタノール $210 \mathrm{ml}$ お。 よび $5 \%$ パラジウムー炭素触媒 $0.8 \mathrm{~g}$ の混合物をふりまぜると しだいに発熱し，ついには沸騰するに至った。そのまま 2.5 時間 加熱還流させ，熱時こしわけて触媒を除き，口液を濃縮して mp 95 98 ${ }^{\circ} \mathrm{C}$ のジアミン $20 \mathrm{~g}$ (定量的)を党た。ベンゼンから再結 晶して $\mathrm{mp} 97 \sim 98^{\circ} \mathrm{C}$ 。

分析値 F $16.2 \%, \mathrm{~N} 11.9 \%$

$\mathrm{C}_{12} \mathrm{H}_{10} \mathrm{~F}_{2} \mathrm{~N}_{2} \mathrm{O}$ としての計算値 F $16.1 \%, \mathrm{~N} 11.9 \%$

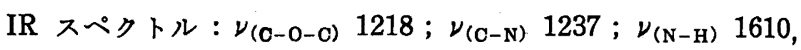
$1640, \quad 3240 \sim 3430 ; \nu_{(\mathrm{C}-\mathrm{F})} 1107,1122 \mathrm{~cm}^{-1}$ 。

このジアミンの熱ベンゼン溶液に無水酢酸を加えると，ただち にジアセチル化物の結晶を析出した。希酢酸から再結晶して $\mathrm{mp}$ $232 \sim 233^{\circ} \mathrm{C}_{\text {。 }}$

分析値 F $11.7 \%, \mathrm{~N} 8.91 \%$

$\mathrm{C}_{16} \mathrm{H}_{14} \mathrm{~F}_{2} \mathrm{~N}_{2} \mathrm{O}_{3}$ としての計算值 F $11.9 \%$, N 8.75\% また同じくベンゼン溶液に塩化ベンゾイルを加え, ジペンゾイ ル化物をえた。酢酸から再結晶して $\mathrm{mp} 241 \sim 242^{\circ} \mathrm{C}$ 。

分析値 F 8.50\%, N 6.18\%

$\mathrm{C}_{26} \mathrm{H}_{18} \mathrm{~F}_{2} \mathrm{~N}_{2} \mathrm{O}_{3}$ としての計算值 F 8.56\%, N . 6.31\% (1968 年 4 月, 日本化学会第 21 年会発表)

元素分析を担当された松本洋子, 大和田弘子両氏にあつく感謝 します。

\title{
四酢酸鉛によるメタクリル酸メチルの重 合*1
}

（昭 和 43 年 7 月 10 日 受 理)

青木 修三・中谷 良三・大津 隆 行*2

\section{1 緒言}

ある種の金属アセチルアセトナートがビニルモノマーのラジカ ル重合開始剤として働くことは，すで詳しく研究されておりよ く知られている。この重合系の開始種は（1）で示されるよ5に 金属-酸素結合の homolysis で生じたリガンドラジカルであると されている1 3)。

一方, カルポン酸鉛塩は (2) 飞従って分解し, やはり金属一 酸素結合の homolysis からラジカルを生成することが知られて いる4)。ここで生じたラジカルもビニル重合の開始能を有するこ

*1 本報を「金属を含む開始郕系（第 15 報）」とする.

*2 Shuzo AOKI, Ryozo NAKATANI, Takayuki OTSU 大 阪市立大学工学部応用化学科 : 大阪市住吉区杉本町.

1）青木修三, 化学, 23，207 (1968).

2) 大津隆行, 南井宣明, 西川幸利, J. Macromol. Sci., A, 2, 902 (1968).

3）大津隆行, 西川幸利, 青木修三, 工化, 71, 1067 (1968).

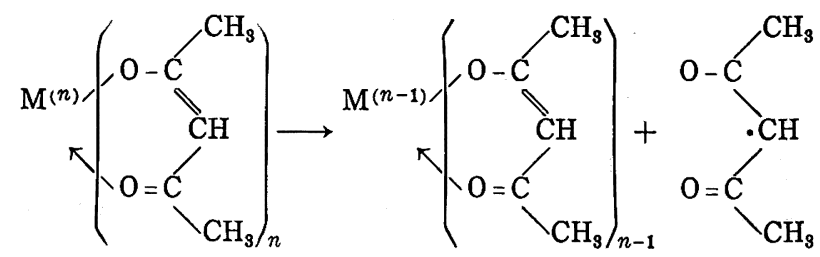

とが予想される。

$$
\mathrm{Pb}(\mathrm{N})\left(\mathrm{O}_{2} \mathrm{CR}\right)_{4} \longrightarrow \mathrm{Pb}(\text { III })\left(\mathrm{O}_{2} \mathrm{CR}\right)_{3}+\mathrm{R} \cdot+\mathrm{CO}_{2}
$$

本報では四酢酸鉛を開始剂とするメタクリル酸メチル (MMA) の重合を試み，これが開始能を有することが見い出されたので報 告する。

\section{2 実験}

四酢酸鉛，イソ吉草酸，塩化リチウムはいずれも和光純薬製試 薬をそのまま使用した。MMA，ピリジン，ベンゼンは市販品を

4) J. K. Kochi, J. Am. Chem. Soc., 87, 1811 (1965). 
常法に従って精製し，使用した。

重合は真空下，封管中で暗黒下にフリマゼ式恒温槽中で所定時 間行なった。生成ポリマーは反応混合物を大量のメタノール中に 投入して分離した。ここで得られたポリマーは，さらにアセトン に溶解し，口過または遠心沈殿によって不溶性鉛化合物を除去し た後, 大量の水を加えてポリマーを析出せしめ, 減圧下に乾燥し た。

\section{3 結 果と考 察}

表 1 に四酢酸鉛による MMA の重合結果を示す。この表から 四酢酸鉛が MMA の重合に対して開始活性を有して拉り，高分 子量ポリマーを生成しらることが明らかにされた。

さらに Kochi ${ }^{4,5)}$ にれば, 四眽酸鉛はピリジン, カルボン 酸, 塩化リチウムなどの添加によって分解が促進されることが報 告されている。そこで本報に括いてもピリジン, イソ吉草酸, 塩 化リチウムについてその添加効果を調べてみた。しかし表 1 の結 果から示されるよ5に, 重合開始という点からはこれらの化合物

表 1 四酢酸鉛による MMA の重合 $\left(60^{\circ} \mathrm{C}\right)^{\mathrm{a})}$

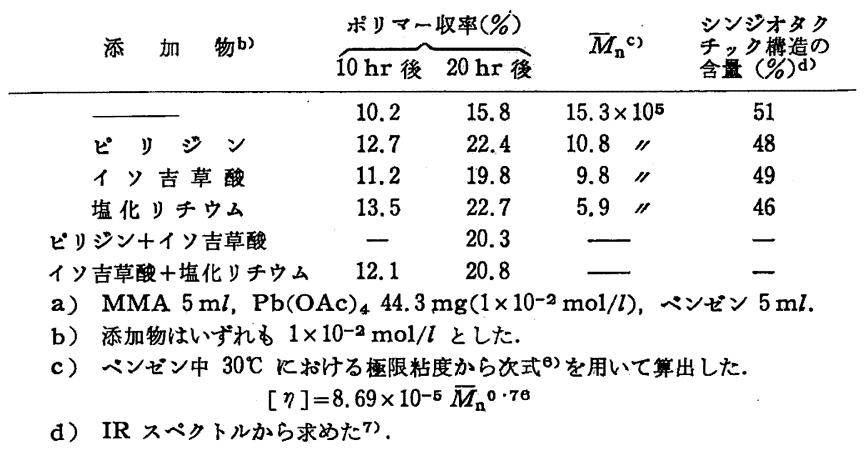

5) J.K. Kochi, J. Org. Chem., 30, 3265 (1965).

6) T.G.Fox, J.B. Kinsinger, H. F. Mason, E. M. Schnele, Polymer, 3, 71 (1962).

7) T.Otsu, B. Yamada, M. Imoto, J. Macromol. Chem., 1, 61 (1965).
の添加効果はほとんど認められなかった。

四䣫酸鉛を用いて得られたポリ MMA のシンジオタクチック 構造の含量は，同様の条件下でアゾビスイソブチロニトリルを用 いて得られたポリマーと一致して和り（約 50\%)，この化合物が ラジカル開始剤として作用していることを示している。したがっ てこの重合系に打ける開始種は，（3）に従って生成するメチル ラジカルと考えることができる。

$\mathrm{Pb}^{(\mathrm{IV})}\left(\mathrm{O}_{2} \mathrm{CCH}_{3}\right)_{4} \longrightarrow \mathrm{Pb}(\mathrm{III})\left(\mathrm{O}_{2} \mathrm{CCH}_{3}\right)_{3}+\cdot \mathrm{CH}_{3}+\mathrm{CO}_{2}$

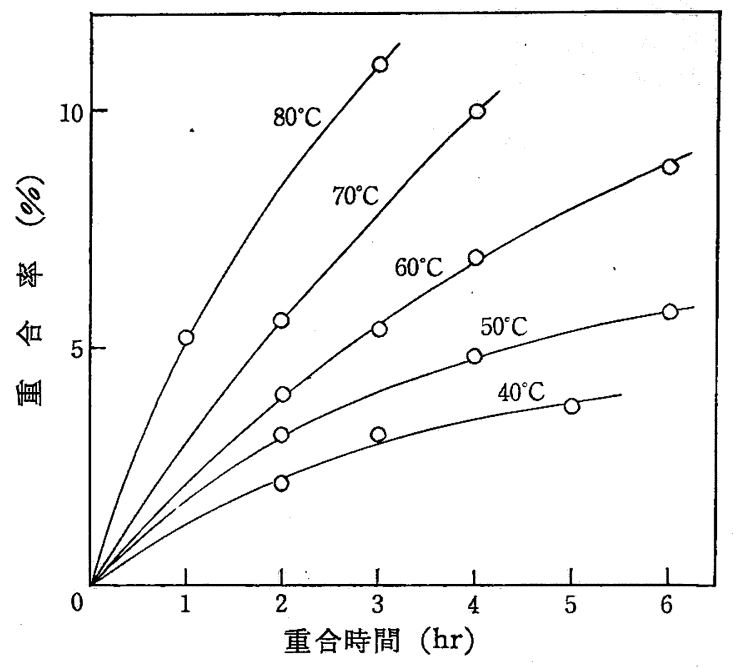

因 1 四酢酸鉛による MMA の重合 MMA $5 \mathrm{ml}$, ベンゼン $5 \mathrm{ml}, \mathrm{Pb}(\mathrm{OAc})_{4} 50 \mathrm{mg}$

図 1 に $40 \sim 80^{\circ} \mathrm{C}$ に拈ける重合時間とポリマー収率の関係を示 す。ポリマー収率は温度ととすに上昇するが, 重合初期より重合 時間とともに重合速度が低下することが認められた。

金属カルボン酸塩による重合については, さらにシクロヘキサ ンカルボン酸塩についてその詳細を追って報告する8。

8）青木修三, 松村済太郎, 大津隆行, 日本化学会第 21 年会 予稿集, N, p. 2897 (1968).

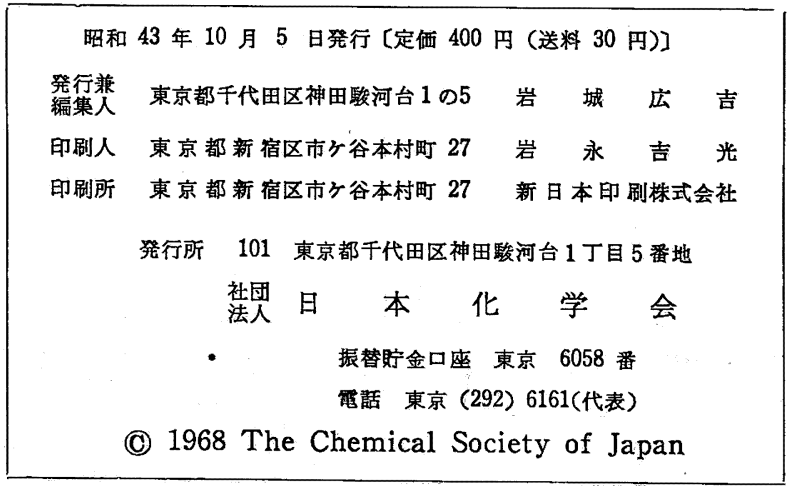

落丁，乱丁がありましたときは早目に括申し出ください。非りかえいたします。 